\title{
FACTOR ANALISIS OF COST OF PRODUCTION IN THE PRODUCTION AND PROCESSING OF MEAT AND MEAT PRODUCTS IN THE STARA ZAGORA
}

\author{
O. Milev* \\ Department "Economics”, Faculty of Economics, Trakia University, Stara Zagora, Bulgaria
}

\begin{abstract}
The goal in this article is to investigate the cost of production in one of the branches of the food industry, namely "production and processing of meat and meat products". The empirical study included 7 companies in Stara Zagora.

In methodological factors, cost analysis includes consideration of the isolated influence of each factor, the amount of output, costs of materials, costs for external services, depreciation and costs for salaries and benefits on the cost by using regression analysis.

The results of the analysis are the demand for strong and weak links between the cost price and the underlying factors. Thus, it is assessed in which factor has a reserve to be used. The conclusion is related to the evaluation of the results of the study and display of summary conclusions and recommendations.
\end{abstract}

Key words: factor analysis, cost of production, food industry, regression analysis

\section{INTRODUCTION}

For a more detailed analysis of average total costs and evaluation of the independent effect of individual factors (raw materials, labor, average productivity etc.), a system of parameters for factor analysis of output costs could be employed. [2]

In general, the function describing the relationship between production costs and the related factors could be presented in the following manner [1, 4]:

Where:

$$
\text { (1) } y=a_{0}+a_{1} x_{1}+\cdots+a_{n} x_{n}
$$

y - resulting sign (output costs)

$\mathrm{a}_{\mathrm{i}}$ - respective regression coefficients

$\mathrm{x}_{\mathrm{i}}$ - values of factors related to output costs

By means of software applications, the following parameters could be computed [3, 5]:

- parameters evaluating the impendent effect of every factor on output costs;

- parameters evaluating the integral impact of all production factors.

\footnotetext{
*Correspondence to: Oleg Milev PhD , Bulgaria, Stara Zagora, Trakia University, Faculty of Economics, Department of Economics, Student campus, +35942699400,

E-mail: georgiev@uni-sz.bg
}

The parameters reflecting the individual effect of production factors on output costs are:

- Regression coefficients $\left(\mathbf{a}_{\mathbf{i}}\right)$. They reflect the absolute influence of a factor and demonstrate the change in output cost in BGN at the background of constant participation of other production factors.

- Coefficients of elasticity $\left(E_{\mathbf{i}}\right)$

Where:

$$
\text { (2) } E_{i}=a_{i} \cdot \overline{\bar{Y}} \overline{\bar{Y}}
$$

$a_{i}$ - regression coefficient for a given factor

$x_{i}$ - arithmetic mean value of the given factor

$\mathbf{y}$ - arithmetic mean of the resulting sign (output costs)

The coefficient of elasticity shows the relative (\%) influence of a given variable on output costs, i.e. the percentage change of output costs (given that all other factors are fixed) in response to $1 \%$ change in a given variable. The coefficient of elasticity overcomes the disadvantage of regression coefficients related to the different dimension units between factors and resulting sign. In this case, the entire influence of a factor on output costs is yielded in percents.

- Standardized regression coefficients $\left(\beta_{i}\right.$ бета коефициенти) 
MILEV O.

(3) $\beta_{i}=a_{i} \cdot \frac{\sigma x_{i}}{\sigma_{y}}$,

Where:

$a_{i}$ - regression coefficients

$\boldsymbol{\sigma} \boldsymbol{x}_{\boldsymbol{i}}$ - standard deviation of the respective factor

$\boldsymbol{\sigma}_{\boldsymbol{y}}$ - standard deviation of the resulting sign (output costs)

Beta coefficients denote the strength, direction and reserves of every variable with respect to output costs. The nearer the beta value to 1 , the higher the strength and reserves of a variable are; the direction of the influence (increasing or decreasing output costs) depends on the sign before the coefficient.

The parameters reflecting the integral effect of factors (the set of factors) on output costs are:

- Coefficient of determination $\left(\mathbf{R}^{\mathbf{2}}\right)$, which denotes the relative proportion (\%) of factors' influence, i.e. how much of the variability of output costs can be explained by its relationship to selected variables. Thus, the coefficient of determination helps understanding if the selected model of output costs factor analysis is good enough.

- Multiple regression coefficient (R). It presents the power of the relationship between independent variables (output costs factors) and the dependent variable (output cost).

\section{OUTPUT COSTS ANALYSIS}

The average total cost of meat and meat products production are outlined in a function of the amount of production, material costs, external services, depreciation costs, wage and insurance costs. Table $\mathbf{1}$ shows the summarized data of output costs (dependent variable) along with data for the above mentioned five independent variables.

Table 1. Factor analysis of average total cost of production of fresh and cooled meat for the period $2008-2012$ /in thousand BGN/

\begin{tabular}{|c|c|c|c|c|c|c|c|}
\hline & & & & & & \\
\hline Years & Companies & $\mathbf{Y}$ & $\left(\mathbf{X}_{1}\right)$ & $\left(\mathbf{X}_{2}\right)$ & $\left(\mathbf{X}_{3}\right)$ & $\left(\mathbf{X}_{4}\right)$ & $\left(\mathbf{X}_{5}\right)$ \\
\hline \multirow{7}{*}{ ڤ్స } & $\mathrm{A} 1$ & 4,05 & 2103 & 6360 & 1060 & 540 & 554 \\
\hline & $\mathrm{A} 2$ & 6,08 & 237 & 839 & 528 & 11 & 65 \\
\hline & A3 & 4,26 & 4631 & 17560 & 740 & 1020 & 419 \\
\hline & A4 & 4,08 & 404 & 1486 & 34 & 79 & 48 \\
\hline & A5 & 5,30 & 9 & 36 & 2 & 6 & 6 \\
\hline & A6 & 3,92 & 23 & 56 & 5 & 4 & 27 \\
\hline & A7 & 3,70 & 34 & 29 & 6 & 6 & 18 \\
\hline \multirow{7}{*}{ ڤ્సે } & $\mathrm{A} 1$ & 4,05 & 2210 & 6680 & 1090 & 601 & 573 \\
\hline & $\mathrm{A} 2$ & 5,86 & 278 & 947 & 597 & 14 & 71 \\
\hline & A3 & 4,25 & 4734 & 17863 & 768 & 1066 & 427 \\
\hline & A4 & 4,05 & 422 & 1533 & 37 & 84 & 53 \\
\hline & A5 & 5,28 & 10 & 38 & 2 & 6 & 6 \\
\hline & A6 & 4,26 & 23 & 58 & 6 & 5 & 28 \\
\hline & A7 & 3,73 & 37 & 31 & 7 & 6 & 19 \\
\hline \multirow{7}{*}{ 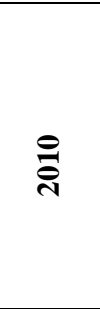 } & A1 & 3,90 & 3419 & 11254 & 987 & 374 & 736 \\
\hline & A2 & 3,87 & 338 & 1098 & 69 & 47 & 93 \\
\hline & A3 & 3,87 & 5920 & 19070 & 1129 & 2152 & 585 \\
\hline & $\mathrm{A} 4$ & 4,20 & 469 & 1674 & 61 & 154 & 80 \\
\hline & A5 & 5,39 & 10 & 40 & 2 & 7 & 7 \\
\hline & A6 & 5,10 & 24 & 87 & 5 & 2 & 28 \\
\hline & A7 & 2,02 & 23 & 15 & 8 & 5 & 18 \\
\hline \multirow{7}{*}{$\bar{\Xi}$} & A1 & 3,90 & 4382 & 14424 & 1089 & 356 & 1200 \\
\hline & $\mathrm{A} 2$ & 3,76 & 382 & 1188 & 56 & 72 & 122 \\
\hline & A3 & 4,30 & 6038 & 22068 & 1075 & 1696 & 1134 \\
\hline & A4 & 4,38 & 505 & 1837 & 76 & 183 & 116 \\
\hline & A5 & 3,54 & 20 & 56 & 2 & 6 & 6 \\
\hline & A6 & 4,33 & 34 & 106 & 6 & 3 & 30 \\
\hline & A7 & 3,84 & 33 & 28 & 8 & 5 & 19 \\
\hline \multirow{7}{*}{$\tilde{\bar{~}}$} & A1 & 4,10 & 4281 & 14391 & 1397 & 711 & 1056 \\
\hline & $\mathrm{A} 2$ & 3,75 & 389 & 1204 & 56 & 73 & 126 \\
\hline & $\mathrm{A} 3$ & 4,11 & 6070 & 21334 & 1280 & 984 & 1372 \\
\hline & A4 & 4,44 & 514 & 2302 & 88 & 171 & 165 \\
\hline & A5 & 4,31 & 16 & 45 & 8 & 6 & 10 \\
\hline & A6 & 4,32 & 32 & 103 & 5 & 3 & 28 \\
\hline & A7 & 3,23 & 57 & 101 & 21 & 24 & 38 \\
\hline
\end{tabular}


Where:

Y - Average total cost /ATC/

$\mathrm{X}_{1}$ - Amount of production

$\mathrm{X}_{2}-$ Material costs

\section{At:}

$$
\begin{aligned}
& \mathbf{a}_{1}=\mathbf{0 , 0 9 9} \\
& \mathbf{a}_{2}=0,363 \\
& \mathbf{a}_{3}=\mathbf{1 , 3 4 3} \\
& \mathbf{a}_{4}=-\mathbf{0 , 6 2 8} \\
& \mathbf{a}_{5}=-\mathbf{1 , 7 6 2} \\
& \mathbf{R}^{2}=\mathbf{0 , 6 3}
\end{aligned}
$$

$\mathrm{X}_{3}-$ External services costs

$\mathrm{X}_{4}$ - Depreciation costs

$\mathrm{X}_{5}-$ Wage and insurance costs
Before analyzing the output costs of the branch production and processing of meat and meat products, it should be taken into consideration that baseline data were from the activity with the highest relative proportion among all $40 \%$, namely "Production of fresh and cooled meat".

The analysis comprised the period from 2008 to 2012. The included five production cost variables were responsible for the $63 \%$ of the total influence on the dependent variable $/ \mathrm{R}^{2}$ $=0.63 /$, which allows affirming that the model was good and that the results from the analysis of individual effects of factors could serve as a basis for reliable conclusions.

The multiple correlation coefficient was also high, demonstrating a strong relationship between output costs and production-related factors.

The highest absolute effect on average total cost reduction was that of the wage and insurance costs $/ a_{5}=-1,76 /$, followed by depreciation costs $/ a_{4}=-0,63 /$. With respect to increase in output costs, the external services costs were highly influential $/ \mathrm{a}_{3}=1,34 /$, allowing assuming that enterprises producing fresh and cooled meat should optimize these costs and to seek ways to reduce them.

Coefficients of elasticity showed similar tendencies as numeric values. Thus, $1 \%$ reduction of depreciation costs results in $0.45 \%$ reduction of output costs $/ \mathrm{E}_{4}=-0,447 /$. Therefore, depreciation costs possess a great potential for reduction of output costs. The effect of material costs $/ \mathrm{E}_{2}=0,41 /$ was evaluated as substantial for increase of production costs.

Standardized regression coefficients exhibited the greatest effect and potential for reduction of output costs as wage and insurance costs $/ \beta_{5}$ $=-0,93 /$ and external services costs $/ \beta_{3}=0,88 /$ were concerned.

\section{CONCLUSION}

To sum up, the following conclusions could be made:

The factor analysis of output costs on the basis of five variables - amount of production, material costs, external services, depreciation costs, wage and insurance costs - could be evaluated as reliable because the model was characterized with high factor effects. The relationship between the output costs and above mentioned factors was strong.

Unfortunately, all these factors for fresh and cooled meat producing enterprises act towards increase in output costs which a prerequisite is seeking opportunities for optimization of costs related to external services.

Various factors act to decrease or increase the average total cost, which means that the effect of negative factor should be compensated with different means and tools in order to decrease output costs.

\section{REFERENCES}

1. Аркадиев, Д., Иконометрия. Ст. Загора, Издателство CON-CAR, 2000.

2. Милев, О., Рентабилност на Хранителната индустрия в област Стара Загора, Дисертация, Стара Загора, 2014.

3. Николов, Н., Финансов анализ на стопанската дейност, УНСС, 1993.

4. Петков, Пл., Иконометрия с Gretl и Excel®. Свищов, АИ „Ценов”, 2010.

5. Чуков, Хр., Финансово-стопански анализ на предприятието, Тракия-М, София, 2003, c.30, 161. 